\title{
Modulation of Tularemia Disease Progress by the Bisquaternary Pyridinium Oxime HI-6
}

\author{
Miroslav Pohanka ${ }^{1,2}$, Oto Pavliš̌ ${ }^{2,3}$, Jiří Pikula ${ }^{4}$, František Treml ${ }^{5}$, Kamil Kuca ${ }^{1,2}$ \\ ${ }^{1}$ Centre of Advanced Studies, ${ }^{2}$ Department of Toxicology, Faculty of Military Health Sciences, \\ University of Defence, Hradec Králové, Czech Republic \\ ${ }^{3}$ Centre of Biological Defence, Těchonín, Czech Republic \\ ${ }^{4}$ Department of Veterinary Ecology and Environmental Protection, Faculty of Veterinary Hygiene and Ecology, \\ ${ }^{5}$ Department of Infectious Diseases and Epizootiology, Faculty of Veterinary Medicine, University of Veterinary \\ and Pharmaceutical Sciences Brno, Czech Republic
}

Received October 8, 2008

Accepted April 6, 2010

\begin{abstract}
Cholinesterase reactivator HI-6 is a drug commonly used to treat individuals exposed to nerve agents. Recent experiments proved HI-6 impact on parasympathetic response and impact on the nervus vagus associated cholinergic anti-inflammatory pathway is hypothesized here. The modulation effect of HI-6 was studied on BALB/c mice infected with Francisella tularensis, the bacteria causing tularemia. Cultivation test in vitro confirmed weak bacteriostatic effects of HI-6. Results in experiments revealed intriguing effect differences resulting from HI-6 administration to mice. While the HI-6 dose of $7 \mathrm{mg}$ per animal (pro toto) had no significant effects on infection progress, lower dose of $8 \mu \mathrm{g}$ of HI-6 pro toto reduced mice mortality caused by tularemia infection compared to control group of mice infected only with $F$. tularensis (survival curves were compared by the logrank test, chi square $=4.335, \mathrm{df}=1, P=0.0373$ ). The effect observed in mice exceeded the effect provided in vitro on bacterial cultures. Though the exact molecular mechanism of HI-6 modulation during infection should be investigated, HI-6 is seems to be suitable as immunomodulans.
\end{abstract}

Asoxime, immunity, infection progress, Francisella tularensis, cholinesterase, inflammation

Military nerve agents, some pesticides and other drugs are organophosphate compounds capable of inducing irreversible inhibition of important enzyme acetylcholinesterase (AChE; EC 3.1.1.7) by binding into serine hydroxyl in enzyme active site (Bajgar 2004). Intoxication with organophosphates results in partial or full dysfunction of neurosynapses since acetylcholine is an important neurotransmitter and AChE participates in relaxation of neurosynapses by hydrolysis of acetylcholine (Sillman and Sussman 2005). Although organophosphates are bound in the cholinesterase active centre irreversibly and covalently, some strategies of the suppression of the negative effect were found. Anticholinergic drugs such as atropine and/or AChE oxime reactivators such as HI-6 (also known as asoxime) are able to reduce intoxication effect (Goel and Aggarwal 2007). Reactivators are strongly effective for treatment of intoxication by organophosphates. Their chemical structures include not only the oxime group but also quaternary ammonium group (pyridinium) for a better interception in the active site of cholinesterase (Bajgar 2004). Quaternary amino group is also included in some disinfectants e.g. benzalkonium chloride (Rutala and Weber 1999; Chaidez et al. 2007). Furthermore, imines are effective in the form of polymers (Zhang et al. 2007).

The aim of our study was to find out what happens after administering a reactivator to organisms exposed to an infection with expected high mortality; furthermore, whether the dose of the reactivator used for prophylactic purposes can improve or worsen the progress of infection. An increase in mortality because of toxicological stress, or a positive effect due to bacteriostatic action or on the contrary, bactericidal action of the reactivator could be expected. The gram negative bacterium and causative agent of tularemia, Francisella

Address for correspondence:

Miroslav Pohanka

Centre of Advanced Studies, Department of Toxicology

Faculty of Military Health Sciences

Phone: +420973253091

University of Defense, Hradec Králové, Czech Republic 
tularensis was selected as a model pathogenic microorganism that can be abused as a biological warfare agent (Nigrovic and Wingerter 2008). Laboratory mice are often used in studies on tularemia pathogenesis (Bandouchova et al. 2009a; Bandouchova et al. 2009b). The infection is a typical zoonosis (Feldman 2003), so the similar results can be expected in humans.

\section{Materials and Methods}

Microorganism and its cultivation

Francisella tularensis LVS (American Type Culture Collection ATCC 29684) used in the experiment was cryopreserved in a box with liquid nitrogen. McLeod agar supplemented with bovine haemoglobin and Iso VitaleX (Becton-Dickinson, San Jose, CA, USA) was used for cultivation purposes according to Pohanka (2007). After approximately two days, bacterial colonies were harvested, washed, and suspended in saline. Cell concentration in suspension was estimated using cell density meter (WPA, Cambridge, UK). The exact colony forming units $(\mathrm{CFU})$ was estimated by recultivation.

HI-6 antibacterial activity assay

Evaluation of mortality in mice infected by F. tularensis should provide answers to following questions. Could HI-6 administration influence mortality when attack with chemical and biological weapons is confused? In other words, is there any treatment effect of HI-6 given to an individual suffering from a model disease of tularemia? We decided to evaluate the progress of mortality as an output value proportional or disproportional to the dose of HI-6. The diffusion method was used to evaluate sensitivity of F. tularensis LVS to HI-6 in vitro effect. Different concentrations of HI-6 (1-(2-hydroxyiminomethylpyridinium)-3-(4-carbamoylpyridinium)-2oxapropane dichloride) were injected into disc cuts of filter paper (circle shaped, $0.5 \mathrm{~cm}$ in diameter, sterilized by UV light) and given onto McLeod agar together with the F. tularensis inoculum spread over the agar. Antibacterial effects of HI-6 was observed after two days in culture as a zone of inhibition (the distance from the outer edge of inhibition zone to the edge of filter paper). Bactericidal effect was evaluated using the dilution method. The culture on McLeod agar was overlaid with HI-6 solution and left for $5 \mathrm{~h}$. After that, the culture was suspended into solution, washed by centrifugation $(3,000 \times g$ for $10 \mathrm{~min})$ using phosphate buffered saline (PBS) and finally spread over a new McLeod agar and let to incubate at $37^{\circ} \mathrm{C}$.

In vivo experiment using $\mathrm{BALB} / \mathrm{c}$ mice

A total of 100 female BALB/c mice (BioTest Konarovice, Czech Republic), six weeks old, weighing $24 \mathrm{~g}$ were held in quarantine for ten days. Access to food and water was provided ad libitum throughout the whole experiment. The mice were kept in an air conditioned room $\left(22 \pm 2{ }^{\circ} \mathrm{C}\right)$ with controlled humidity $(50 \pm 10 \%)$ and light $(7: 00 \mathrm{~h}$ to $19: 00 \mathrm{~h})$ at the vivarium centre. The experiment was approved and supervised by the ethics committee.

After the quarantine, the mice were divided into two groups each divided into 5 subgroups (10 mice in one subgroup). The 5 subgroups in both groups were dosed with HI-6 and/or F. tularensis as follows: only F. tularensis (sub-group1), F. tularensis and 10\% dose of the stock (see in text) HI-6 (sub-group 2), F. tularensis and 50\% dose of stock HI-6 (sub-group 3), F. tularensis and 100\% dose of stock HI-6 (sub-group 4) and 100\% dose of stock HI-6 (sub-group 5).

The concentration of $F$. tularensis was adjusted up to $2.0 \times 10^{9} \mathrm{CFU} / \mathrm{ml}$ using cell density meter. Cultivation test provided the exact concentration of $2.6 \times 10^{9} \mathrm{CFU} / \mathrm{ml}$ for the first group of mice (exposed to $40 \mu \mathrm{g} / \mathrm{ml} \mathrm{stock}$ solution of HI-6) and $2.3 \times 10^{9} \mathrm{CFU} / \mathrm{ml}$ for the second group of mice (exposed to $70 \mathrm{mg} / \mathrm{ml}$ stock solution of HI-6). A $100 \%$ dose of HI-6 reactivator (suspension in saline) was $4 \mu \mathrm{g} /$ mice $(40 \mu \mathrm{g} / \mathrm{ml} \mathrm{stock}$ solution) for group 1 and $7 \mathrm{mg} / \mathrm{mice}$ ( $70 \mathrm{mg} / \mathrm{ml}$ stock solution) for group 2 that approximately correspond to $25 \%$ of $\mathrm{LD}_{50}$ (Bartosova et al. 2006). The solutions with $10 \%$ and $50 \%$ of stock HI-6 were obtained by dilution. Both F. tularensis and HI-6 were applied subcutaneously into the pelvic limb at the amount of $100 \mu$ l. The solution of F. tularensis was given first. The HI-6 solution was given $1 \mathrm{~h}$ later. The mice were kept and observed for symptoms of tularemia and mortality. Thirty days after the beginning of experiment, mice were sacrificed and bled under $\mathrm{CO}_{2}$ anaesthesia from the cervical artery.

Blood processing and solid phase extraction

Blood was kept in an incubator at $37^{\circ} \mathrm{C}$ for $30 \mathrm{~min}$. The resulting blood clot was sucked out and crude serum was incubated at $4{ }^{\circ} \mathrm{C}$ for another $30 \mathrm{~min}$. Finally, the obtained serum was centrifuged twice at $3,000 \times g$ for $3 \mathrm{~min}$.

Affine solid phase extraction was used for estimation of the content of antibodies. Protein L was chosen as a molecule able to interact with Fc part of antibodies from different organisms including mice. Protein $\mathrm{L}$ was covalently bound on cellulose matrix (CBindL) (Sigma-Aldrich, St. Louis, MO, USA). Simple column with one frit was filled with CBindL and kept in PBS. Measuring setup was used in the same way as mentioned in Pohanka (2007). Immunoglobulins were eluted with $100 \mathrm{mM}$ glycine pH 2.2. Furthermore, $20 \mathrm{mM}$ Tris/ $\mathrm{HCl}$ pH 7.5 containing $6 \mathrm{M}$ guanidine hydrochloride was used for column cleaning purposes. Remains of the cleaning solution were washed out by 20 column volumes of PBS. 
Statistical analysis

Survival curves of mice were compared using the logrank test and calculating two-tailed $P$ values. Median survival values, i.e. the time by which half of the animals had died following experimental infection, were also calculated. GraphPad Prism 4 (GraphPad Software, San Diego, USA) was used for statistical analyses and graphing data.

\section{Results}

Bacteriostatic and bactericidal effect of HI-6

First, we tested whether HI-6 is able to influence the growth of F. tularensis or act as a bactericidal agent. No bactericidal effect was observed using the dilution test; but a bacteriostatic effect was observed when $100 \mathrm{mM} \mathrm{HI}-6$ was injected into filter paper at the amount of $10 \mu \mathrm{l}$. The size of inhibition zone was $5.5 \pm 3.0 \mathrm{~mm}$. Because of the confirmed bacteriostatic effect in the growth culture of $F$. tularensis, we decided to conduct further experiments to investigate the influence of HI- 6 on tularemia pathogenesis in mice.

\section{Mortality of mice infected by $F$. tularensis}

The first deaths of mice were observed on day 3 after HI- 6 and F. tularensis administration. The last cases of mortality were observed on day 7. Figs 1 and 2 show mortality in mice receiving $40 \mu \mathrm{g} / \mathrm{ml}$ and $70 \mathrm{mg} / \mathrm{ml}$ stock solution of HI-6, respectively. After ten days, mice that resolved tularemia were healthy and there was no significant difference to the controls.

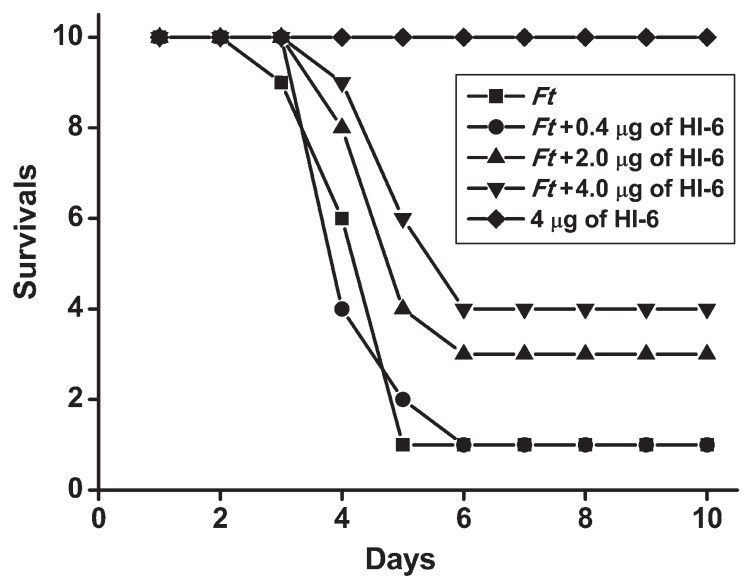

Fig. 1. Mortality of BALB/c mice exposed to s.c. inoculation of $100 \mu$ including $2.6 \times 10^{8}$ F. tularensis (Ft) viable cells and/or another $100 \mu \mathrm{l}$ of HI-6 (the absolute dose indicated in the figure).

The course of infection in mice exposed to tularemia only corresponds to the previous study (Pohanka 2007). The first symptoms (apathy and prickliness) of infection were observed within day 1 after $F$. tularensis inoculation. On day 2, mice were suffering from tularemia. Symptoms such as bristled hair coat and decreased mobility were typical for the first phase of infection. The progress culminated approximately on day 5 . Surviving mice were healthy after approximately day 10 and had no difference in behaviour in comparison with the controls.

The lower dose of HI-6 resulted in different symptoms and mortality. Even the perception of surroundings was present in all groups, especially the group of mice receiving $100 \%$ of the higher concentration of HI-6. Symptoms of tularemia correlated with mortality. The most striking tularemia symptoms were observed at the same time as mortality occurred. 


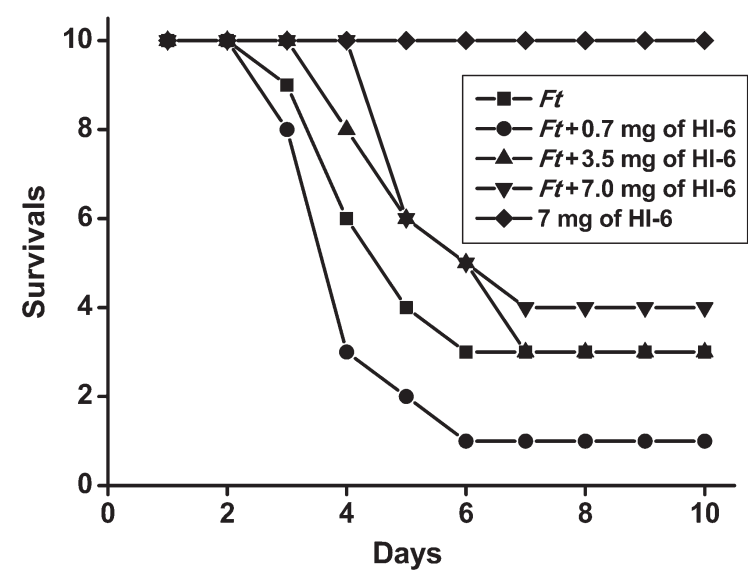

Fig. 2. Mice exposed to $2.3 \times 10^{9} \mathrm{CFU} / \mathrm{ml}$ of F. tularensis (Ft) and $100 \mu \mathrm{l}$ of HI-6 dose (indicated in the figure)

We evaluated the production of antibodies, but no significant changes were observed. Immunoglobulins rised in all groups of mice except the group exposed to only HI-6. Similar results were obtained by Pohanka (2007)

Groups of mice exposed to the lower dose of HI-6 (40 $\mu \mathrm{g} / \mathrm{ml}$ of stock solution) showed a decrease in mortality above the probability level of 0.01 for $100 \%$ of stock concentration. In groups exposed to $50 \%$ of stock concentration the probability level of mortality decreased above 0.05 . The last group ( $10 \%$ of stock concentration) showed the same mortality as the group exposed to tularemia only. Groups exposed to the higher dose of HI-6 $(70 \mathrm{mg} / \mathrm{ml}$ stock concentration) reacted in a different way. There were no significant differences in the mortality rates and no correlation between doses and mortality; one group (10\% of stock concentration) had fewer survivors than the group infected by F. tularensis only. Differences in mortality of groups 1 and 2 infected only by F. tularensis without administration of HI-6 could be caused by slightly different doses of $F$. tularensis.

\section{Discussion}

For the in vitro tests, the data significantly demonstrate the effects of the tested substance on bacterial growth. We cannot explain this fact and we did not find any relevant reference in literature. Benzalkonia salts have slight structural similarity to HI-6. These salts are considered to be antimicrobial agents just due to presence of quaternal ammonium (Chaidez et al. 2007). For in vivo impact, HI-6 is toxic at higher concentrations (Bartosova et al. 2006) as well as a strong competitive inhibitor of acetylcholinesterase and butyrylcholinesterase (Pohanka et al. 2007), the dose equal to approximately 25\% of $\mathrm{LD}_{50}$ had no significant effect on mice mortality. We could clearly propose dosing of HI-6 to individuals endangered by nerve agents with a concurrent infectious disease. The upper dose of HI- 6 can be toxic stress in organism though slight bacteriostatic effect can be expected. The lower dose of HI-6 yielded in a different result. The lower mortality of mice exposed to HI-6 (40 $\mu \mathrm{g} / \mathrm{ml}$ of stock concentration) compared to mice injected only with tularemia can be explained by higher efficacy of bacteriostatic effect while the toxic effect is reduced. Efficacy of HI-6 for treatment of tularemia is probably based on a different mechanism than administration of streptomycin and gentamicin used in medical practice (Enderlin et al. 1994; Cross et al. 1995) because of different functional groups in its molecules. We suppose quaternary ammonium to be the most important structure 
responsible for efficacy of HI-6 against $F$. tularensis. This organic group is important when HI-6 is used as an acetylcholinesterase reactivator and plays a role in capturing molecules in the reaction centre (Bajgar 2004). This group is able to adhere to the negatively charged molecules including cell wall structures; the oxime group could act as a chemical modifier. Beside slight and probably not very effective bacteriostatic effect, HI- 6 is considered to be a compound modulating AChE activity by non-competitive inhibition (Pohanka et al. 2007) as well as acetylcholine receptors (Soukup et al. 2008; Pohanka et al. 2009). The dose-dependent modification of cholinergic antiinflammatory pathway consisting of blood AChE and nicotine acetylcholine receptor on macrophages (Tracey 2007) is hypothesized as a possible mechanism of HI-6 effect. We suppose that HI-6 have a positive effect on treatment of tularemia. However, other experiments including e.g. effects of other oximes are needed. Especially, the discussed implication of acetylcholine receptors in probability to survive augment should be further investigated.

\section{Modulace progrese tularemického onemocnění za použití biskvarterního pyridinium oximu HI-6}

Reaktivátor cholinesteras HI-6 je účinná látka používaná k léčbě jedinců exponovaných nervově paralytickými látkami. Minulé experimenty nastínily pravděpodobné působení látky HI-6 na parasympatikus a v této práci je diskutováno možné ovlivnění cholinergní protizánětlivé dráhy. V této práci byl sledován vliv látky HI-6 na probíhající tularemické onemocnění. Byly použity myši BALB/c a původce tularemie mikroorganizmus Francisellatularensis. KultivačnítestpotvrdilslabýbakteriostatickýefektlátkyHI-6.Invivo experimenty prokázaly ambivalentní vliv látky HI-6 na smrtnost laboratorních zvírat. Zatímco dávka $7 \mathrm{mg}$ na jedno zvíře (pro toto) nezpůsobila signifikantní pokles smrtnosti, nižší dávky $(8 \mu \mathrm{g})$ signifikantně redukovaly mortalitu jedinců ve srovnání s kontrolní skupinou (longrank test, chí kvadrát $=4,335$, df $=1, P=0.0373$ ). Efekt látky HI-6 na myši trpící tularemií byl mnohem výraznější, než by odpovídalo bakteriostatickému efektu zpozorovanému in vitro. Ačkoliv molekulární mechanizmus působení látky HI-6 v průběhu infekčního onemocnění není znám a měl by být detailněji charakterizován, lze již nyní tvrdit, že se jedná o látku schopnou provádět modulaci imunitního systému.

\section{Acknowledgement}

The study was supported by the Ministry of Defence of the Czech Republic (Grant No. FVZ0000604).

\section{References}

Bajgar J 2004: Organophosphates/nerve agent poisoning: mechanism of action, diagnosis, prophylaxis, and treatment. Adv Clin Chem 38: 151-216

Bandouchova H, Sedlackova J, Hubalek M, Pohanka M, Peckova L, Treml F, Vitula F, Pikula J 2009a: Susceptibility of selected murine and microtine species to infection by a wild-strain Francisella tularensis subsp. holarctica. Vet Med-Czech 54: 64-74

Bandouchova H, Sedlackova J, Pohanka M, Novotny L, Hubalek M, Treml F, Vitula F, Pikula J 2009b: Tularemia induces different biochemical responses in BALB/c mice and common voles. BMC Infect Dis 9: 101.

Bartosova L, Kuca K, Kunesova G, Jun D 2006: The acute toxicity of acetylcholinesterase reactivators in mice in relation to their structure. Neurotox Res 9: 291-296

Chaidez C, Lopez J, Castro-Del Campo N 2007: Quaternary ammonium compounds: an alternative disinfection method for fresh produce wash water. J Water Health 5: 329-333

Cross JT, Schultze GE, Jacobs RF 1995: Treatment of tularemia with gentamicin in pediatric patients. Pediatr Infect Dis J 14: 151-152

Enderlin G, Morales L, Jacobs RF, Cross TJ 1994: Streptomycin and alternative agents for the treatment of tularemia: review of the literature. Clin Infect Dis 19: 42-47

Feldman KA 2003: Tularemia. J Am Vet Med Assoc 222: 725-730

Goel A, Aggarwal P 2007: Pesticide poisoning. Natl Med J India 20: 182-191 
Nigrovic LE, Wingerter SL 2008: Tularemia. Infect Dis North Am 22: 489-504

Pohanka M 2007: Evaluation of immunoglobulin production during tularaemia infection in BALB/c mouse model. Acta Vet Brno 76: 579-584

Pohanka M, Jun D, Kuca K 2007: Amperometric biosensor for evaluation of competitive cholinesterase inhibition by the reactivator HI-6. Anal Lett 40: 2351-2359

Pohanka M, Karasova JZ, Musilek K, Kuca K, Kassa J 2009: Effect of five acetylcholinesterase reactivators on tabun-intoxicated rats: induction of oxidative stress versus reactivation efficacy. J Appl Toxicol 29: 483-488

Rutala WA, Weber DJ 1999: Infection control: the role of disinfection and sterilization. J Hosp Infect 43: 43-55

Sillman I, Sussman JL 2005: Acetylcholinesterae: classical and non-classical functions and pharmacology. Curr Opin Pharmacol 5: 293-302

Soukup O, Pohanka M, Tobin G, Jun D, Fusek J, Musilek K, Marek J, Kassa J, Kuca K 2008: The effect of HI-6 on cholinesterases and on the cholinergic system of the rat bladder. Neuroendocrinol Lett 29: 759-762

Tracey KJ 2007: Physiology and immunology of the cholinergic antiinflammatory pathway. J Clin Invest 117: 289-296

Zhang X, Gao BJ, Zhu Y, Liu Q 2007: Antimicrobial properties of quaternary polyethyleneimine. Acta Pol Sin 7: $627-632$ 